\title{
The tert-Amino Effect in Heterocyclic Chemistry. Synthesis of Spiro Heterocycles
}

\author{
Elisaveta V. D'yachenko, Tatiana V. Glukhareva, Lyudmila V. Dyudya, Oleg V. Eltsov and Yury \\ Yu. Morzherin* \\ Department of Technology for Organic Synthesis (TOSLab), Urals State Technical University - UPI, \\ 19, Mira str., Ekaterinburg, 620002, Russia. Tel. +7 (343)3754818, Fax: +7(343) 3754135
}

* Author to whom correspondence should be addressed; e-mail: morjerine@htf.ustu.ru

Received: 23 April 2005 / Published: 30 September 2005

\begin{abstract}
The tert-amino reaction effect was examined. A new method to synthesize spiro heterocycles is presented. It was shown that the "tert-amino effect" could be applied to the formation of spiro-fused heterocycles. The formation of spiro compounds proceeds in most cases in good yields in a one-pot reaction.
\end{abstract}

Keywords: Tert-amino effect, cyclization, spiro compounds, Knoevenagel condensation, 1,2,3-thiadiazole, pyrazole, quinoline

The term tert-amino effect was coined by Meth-Cohn and Suschizky [1] to generalize cyclization reactions of certain ortho-substituted N,N-dialkylanilines. Ring closure of ortho-substituted N,Ndialkylaniline derivatives can proceed in three different ways, depending on the nature of $\mathrm{A}=\mathrm{B}$ (Scheme 1). The first path (a) involves ring closure between the ortho substituted and the tert-nitrogen atom. The second path (b) comprises those reactions which involve one of the $\alpha$-methylene groups attached to the atom A, ultimately leading to the formation of five membered rings. The third path (c) involved an analogous reaction of methylene groups and atom B which lead to the formation of a sixmembered ring. The first reaction of this type was reported in 1895 by Pinnow [2]. Most of the early examples of the reaction of compounds with an unsaturated ortho substituted involve groups with at least one heteroatom, such as nitroso [3], nitro [4-5], azo [6], amine [7], azomethine [8-10], carbonyl [11-13] or thiocarbonyl moieties as the ortho substituents [14]. 
Scheme 1.

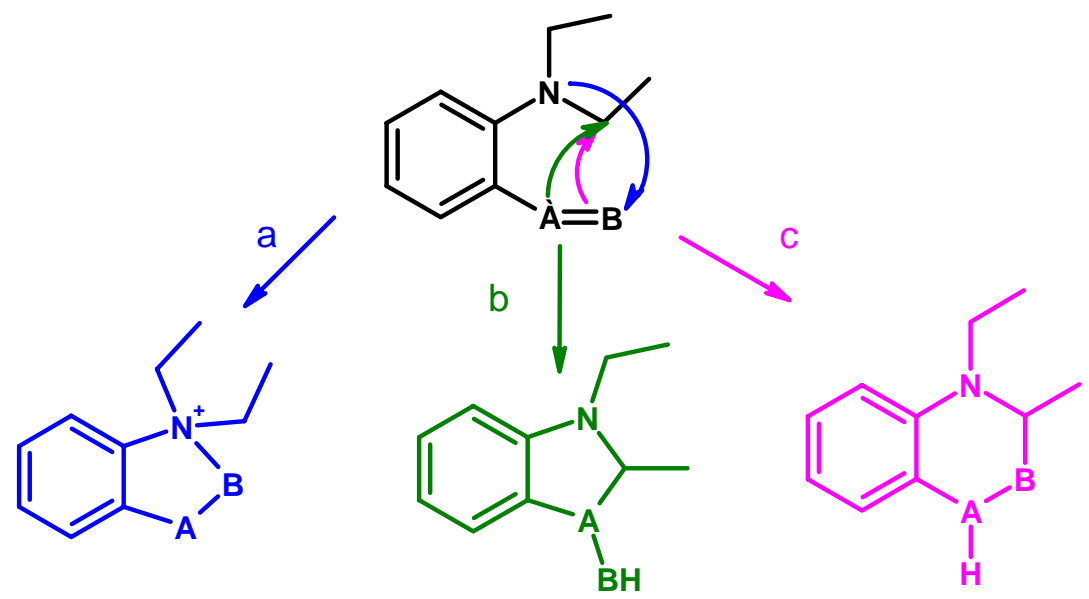

Scheme 2.<smiles></smiles>

N,N-Dialkylanilines having an ortho-vinyl substituent also exhibit the same type ring closure reactions [15-20]. These reactions provide an original way to form $\mathrm{C}-\mathrm{C}$ bonds by insertion into a virtually non-activated $\mathrm{NCH}_{2}$ group [21]. The systematic study of effect of variation in the structure of the vinyl groups revealed that electron-withdrawing group in the $\alpha$-position of the vinyl moieties is essential for 5 membered rings. The heating anilines $\mathbf{1}$ in toluene lead to mixture pyrrolo[1,2-a]indole 
derivatives. In 1-butanol, the reaction is stereospecific: only cis isomer 2 was isolated in $74 \%$ yield [22-23].

\section{Scheme 3.}<smiles>N#C/C=C(/C#N)c1ccccc1N1CCCC1</smiles>

1

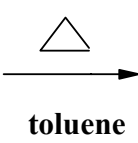

$\mathrm{RCH}_{2} \mathrm{R}$

toluene<smiles>[X]c1ccccc1N1CCCCC1</smiles>

3

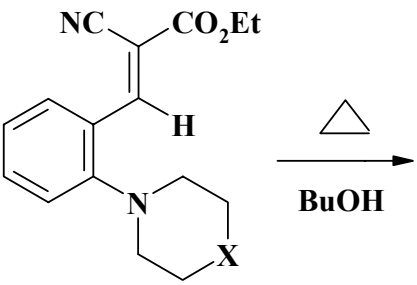

6<smiles>N#CC[C@H]1c2ccccc2N2CCC[C@H]12</smiles>

2

\section{Scheme 4.}<smiles>CCOC(=O)CCCCOC</smiles><smiles>N#CC[C@H]1c2ccccc2N2CCCC12</smiles>

3

When only one electron-withdrawing functionality is present at the $\beta$-position, no reaction takes place. The compounds having two electron-withdrawing groups at the $\beta$-position of the vinyl moiety show a totally different reaction pathway: in this case six-membered rings are formed. Heating of a solution of 2-vinyl-N,N-dialkylanilines 3,6, easily prepared via a nucleophilic substitution of the fluorine atom in 2-fluorobenzaldehyde with secondary amines, followed by Knoevenagel condensation of resulting aldehyde 4 in refluxing butanol yielded cyclization products 5,7 in 67-84\% yields [24-28].<smiles>N#[R]C=Cc1ccccc1N1CC[X]CC1</smiles>

$$
\mathrm{X}=\mathrm{O}(\mathbf{a}), \mathrm{X}=\mathrm{NCH}_{3}(\mathbf{b}), \mathrm{X}=\left(\mathrm{CH}_{2}\right)_{\mathrm{n}} \mathrm{n}=0(\mathbf{c}), 1(\mathbf{d})
$$

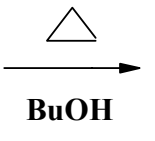<smiles>[X]CC1(C#N)Cc2ccccc2N2CCCCC21C#N</smiles>

7

$67-84 \%$

The mechanism for formation of the six-membered heterocycles is presented in Scheme 5. First step is an intramolecular suprafacial 1,5-hydrogen transfer. The second step involves $\mathrm{C}-\mathrm{C}$ bond formation be addition of the carbanion to the iminium double bond, which takes place in a stereochemically defined unique way. 


\section{Scheme 5.}

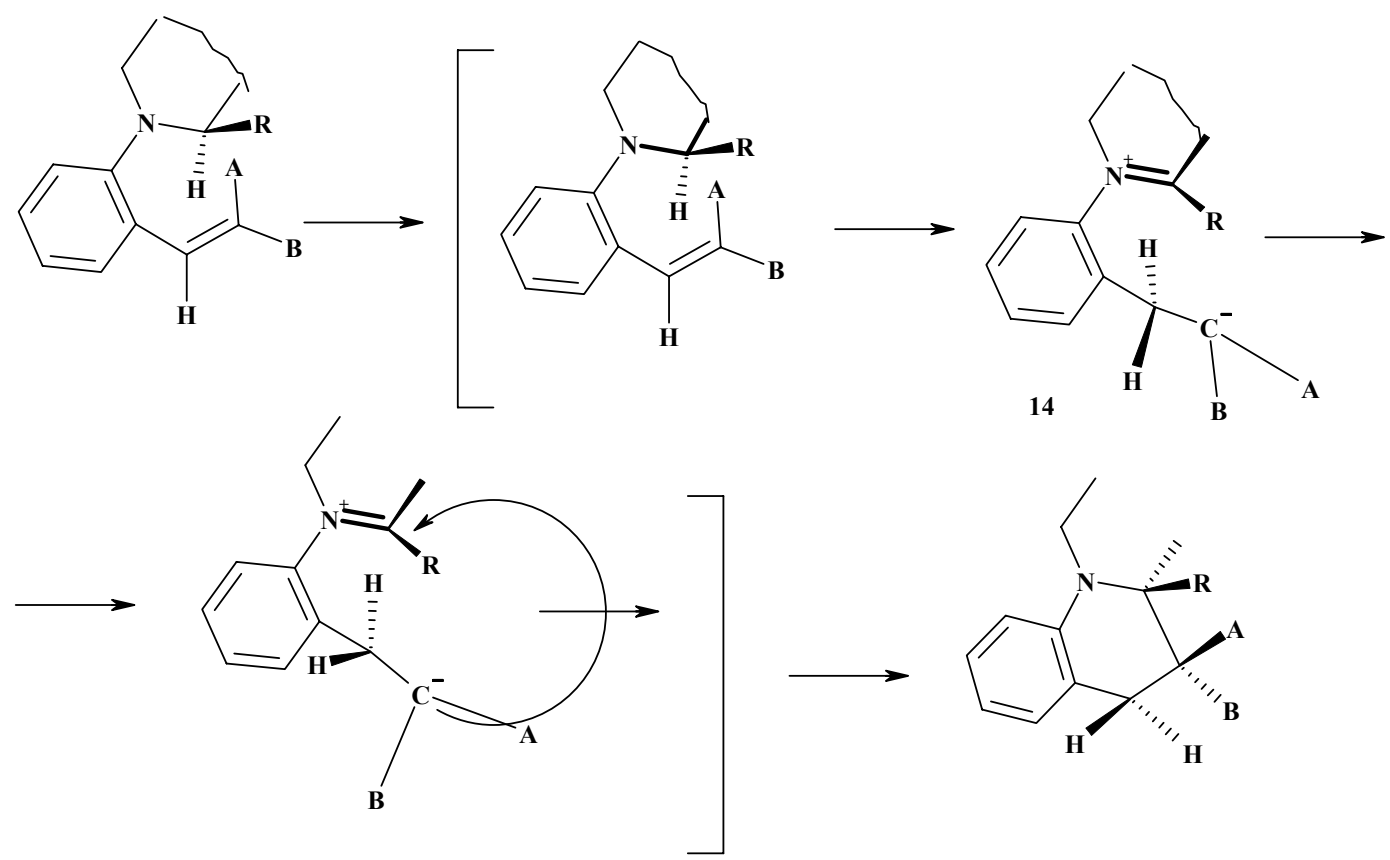

We have shown [29] that under Knoevenagel condensation conditions ortho-N,N-dialkylaminobenzaldehydes 4 form with 2,2-dimethyl-1,3-dioxane-4,6-dione (Meldrum's acid) spiro-coupled pyrrolo[1,2-a]quinolines $\mathbf{8}$. In contrast to the reaction of benzaldehydes with non-cyclic malonic acid derivatives, the intermediate vinyl derivatives 9 were not isolated. Thus we have developed a onestage method for the synthesis of novel spiro derivatives of quinoline. An example of the NMR spectra of product is presented in Figure 1.

\section{Scheme 6.}<smiles>O=Cc1ccccc1N1CCNCC1</smiles>

4<smiles>CC1(C)OC(=O)[CH+]C(=O)O1</smiles>

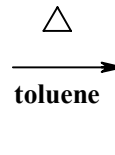

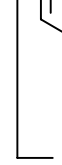

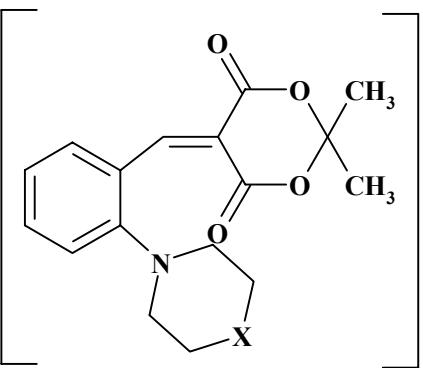

9<smiles>Cc1ccc2c(c1)N1CCCC(C)(C)OC(=O)C1(C(=O)OC(C)(C)O)C2</smiles>

$\mathrm{X}=\mathrm{O}(\mathrm{a}), \mathrm{NMe}(\mathrm{b}), \mathrm{CH}_{2}(\mathrm{c}),\left(\mathrm{CH}_{2}\right)_{2}(\mathrm{~d})$, bond (e) 
Figure 1. The ${ }^{1} \mathrm{H}-\mathrm{NMR}$ spectrum of compounds $\mathbf{8 a}$.

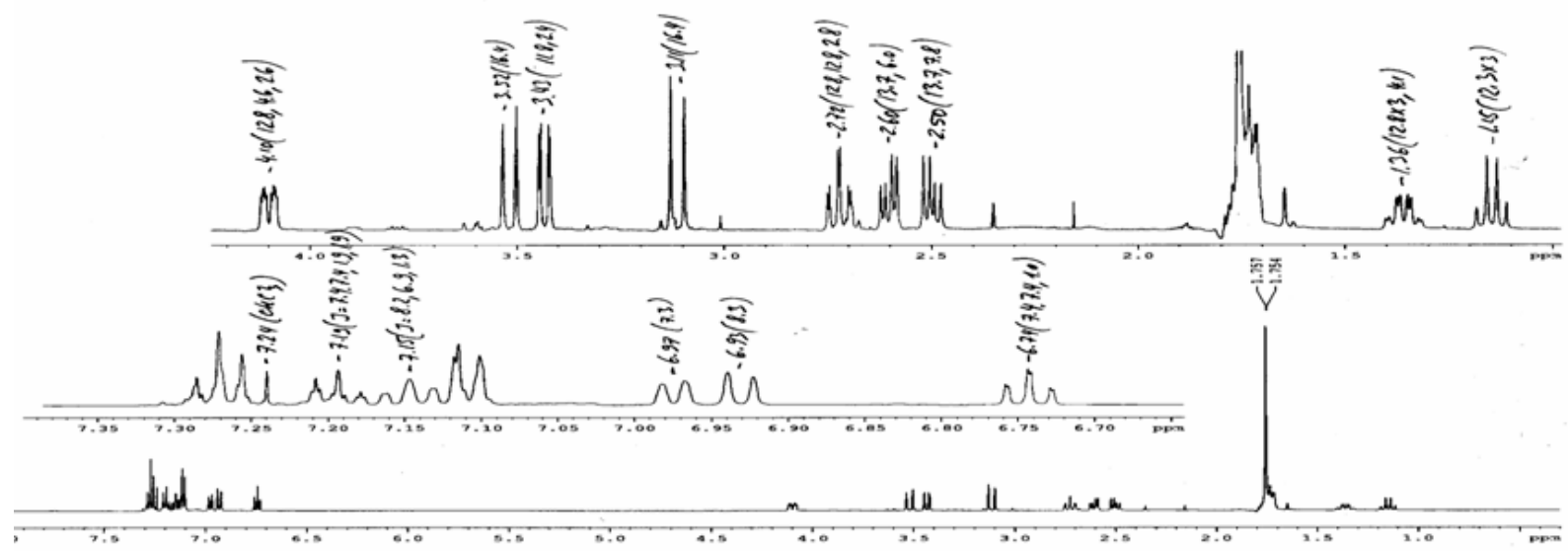

The reactions of 2-dialkylaminobenzaldehydes 4 with cyclohexanedione proceeded analogously [30]. It was demonstrated that the reactions were complete in $10 \mathrm{~h}$ to give spiro-fused [1,2a]quinolines 10, whereas vinyl derivatives were not isolated either. The structures of compounds $\mathbf{1 0}$ were confirmed by NMR, IR, and mass spectra as well as by the results of elemental analysis [31].

\section{Scheme 7.}

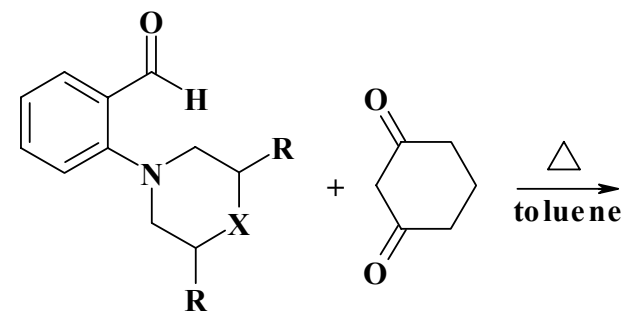

4

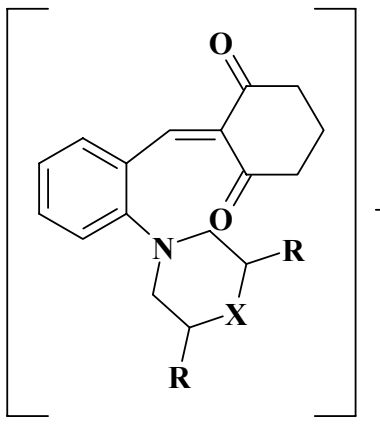

(a) $X=O, R=H$, (b) $X=C_{2}, R=H$, (c) $X=C H P h, R=H$,
(e) $X=-, R=H$, (f) $X=O, R=C_{3}$, (d) $X=\left(C_{2}\right)_{2}, R=H$;

(a) $X=O, R=H$, (b) $X=C_{2}, R=H$, (c) $X=C H P h, R=H$
(e) $X=-, R=H$, (f) $X=O, R=C_{3}$, (d) $X=\left(C_{2}\right)_{2}, R=H$;<smiles>[R]C([X])CN1c2ccccc2CC2(C(=O)CCCC2=O)C1C([R])[X]</smiles>

10

$65-80 \%$

Spiro-fused quinolinepyrimidines $\mathbf{1 1}$ can be synthesized according to two procedures. One of them involves Knoevenagel condensation of 2-dialkylaminobenzaldehydes 4 with malonic ester, cyclization of the resulting benzylidenemalonic esters $\mathbf{3}$ to fused quinolines $\mathbf{5}$ and condensation of the latter with disubstituted urea to give the target products. Another procedure involves the reaction of 2-dialkylaminobenzaldehydes 4 with barbituric acids, where Knoevenagel condensation is accompanied by intramolecular cyclization of intermediate vinyl derivatives. Taking into account the results obtained in earlier studies, it can be assumed that this reaction proceeds in one step to give spiro-fused quinolines 11.

The synthesis of spiro derivatives of quinolines according to the first method involves difficulties associated, in particular, with the formation of by-products. In this connection, isolation of the pure target spiro-fused quinolines presents a problem. The total yield of 11 was 15\%. Their structures were 
confirmed by ${ }^{1} \mathrm{H}$ and ${ }^{13} \mathrm{C}$ NMR and IR spectroscopy, mass spectrometry, and elemental analysis [30$31]$.

Scheme 8.

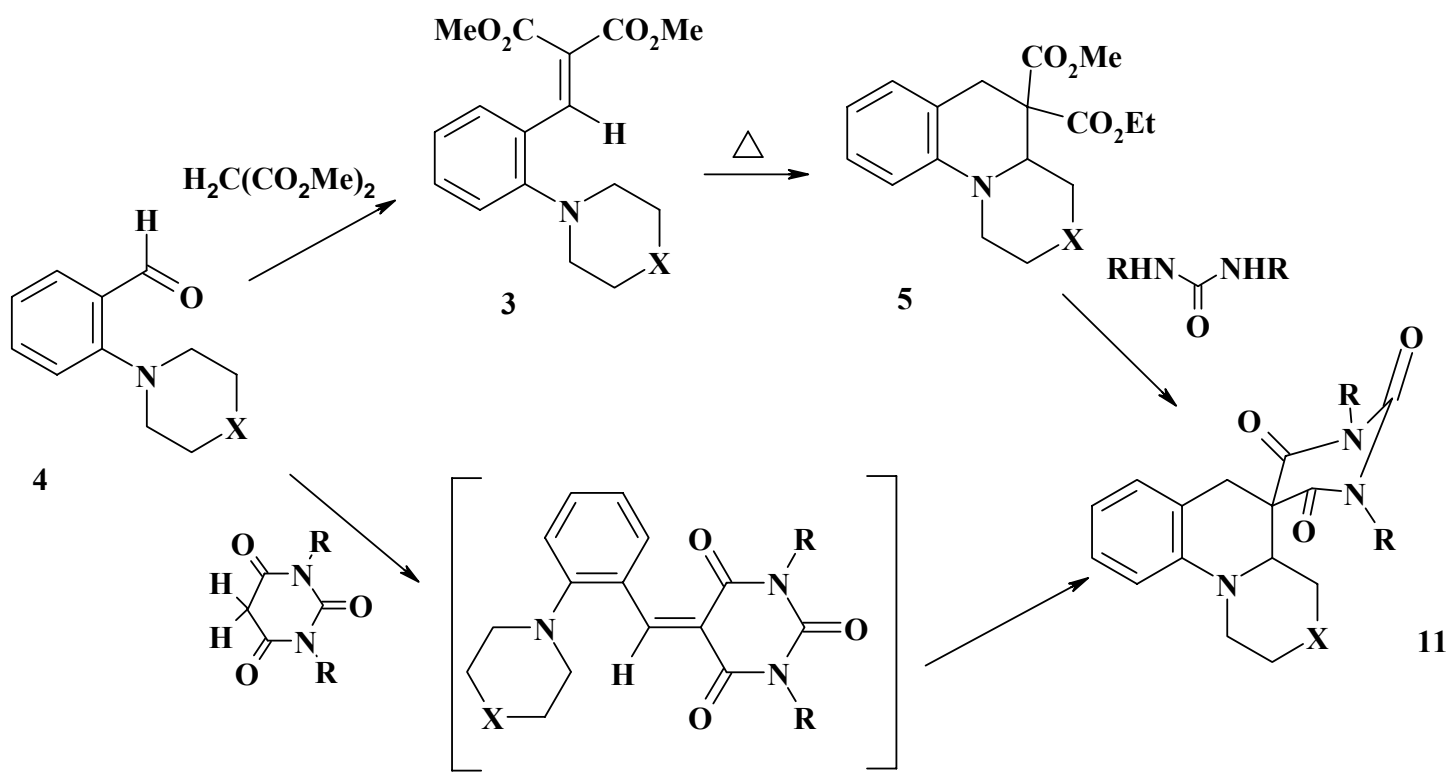

7: $\mathrm{R}=\mathrm{Ph}, \mathrm{X}=\mathrm{O}$ (a), $\mathrm{NMe}(\mathrm{b}), \mathrm{CH}_{2}(\mathrm{c}),\left(\mathrm{CH}_{2}\right)_{2}(\mathrm{~d})$, bond (e)

8: $\mathrm{R}=\mathrm{Me}, \mathrm{X}=\mathrm{O}$ (a), $\mathrm{NMe}(\mathrm{b}), \mathrm{CH}_{2}(\mathrm{c}),\left(\mathrm{CH}_{2}\right)_{2}(\mathrm{~d})$, bond (e)

The second method is preparatively more convenient because it involves one step. We demonstrated that the reactions of 2-dialkylaminobenzaldehydes 4 with dimethyl- and diphenylbarbituric acids afforded spiro compounds 11. It should be noted that cyclization gave spiro-fused quinolines 11 in good yields on refluxing in toluene for $3 \mathrm{~h}$. An increase in the reaction time led to a decrease in the yield and dezincification of the products. In this approach, the total yield of the target products 11 varied from 36 to $70 \%$ [30-31].

Scheme 9.

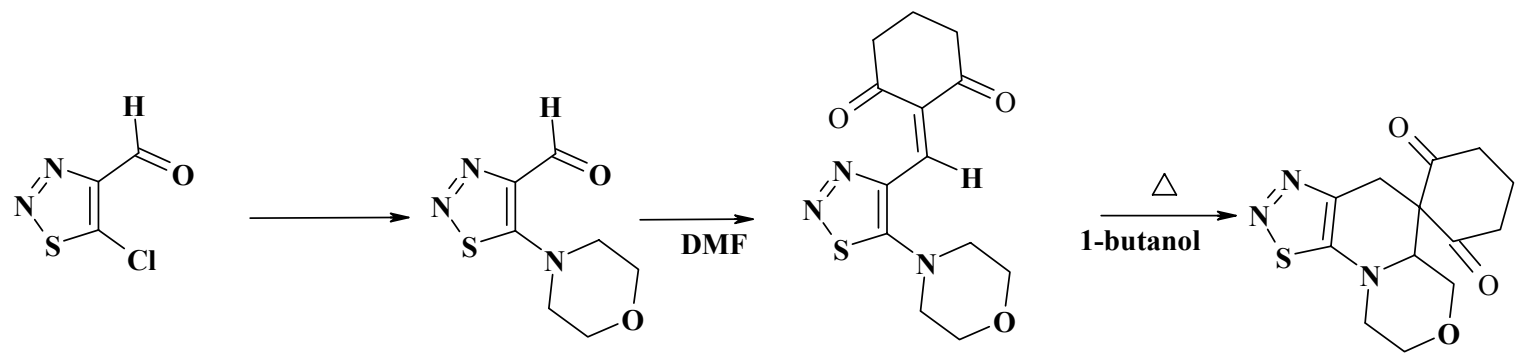<smiles>Cc1nn(-c2ccccc2)c(Cl)c1C=O</smiles><smiles>CC1=C2Cc3c(c(C)nn3-c3ccccc3)CC3(C(=O)CCCC3=O)C3CCCN2C3=NN1c1ccccc1</smiles> 
We used the strategy of the tert-amino effect for the synthesis of a series of new spiro fused heterocycles as a class of compounds which offer biological interest. In contrast in the cyclization reactions of five membered ortho substituted heterocycles 4-vinyl-1,2,3-thiadiazoles 12 or 4-vinyl-1phenylpyrazole 13 were isolated [32].

\section{Conclusions}

We have shown that the "tert-amino effect" can also be applied to the formation of new spiro fused heterocycles. The formation of spiro compounds proceeds in most cases in good yields in a one-pot reaction.

\section{Acknowledgements}

The authors thank the Russian Foundation for Basic Research (grant 05-03-32167).

\section{References}

1. Meth-Cohn, O.; Suschitzky, H. Adv. Heterocycl. Chem. 1972, 14, 211.

2. Pinnow, J. Ber. Dtsch. Chem. Ges. 1895, 28, 3039.

3. Seebach, D.; Enders, D. Angew. Chem. 1975, 87, 1.

4. Fielden, R.; Meth-Cohn, O.; Suschizky, H. J. Chem. Soc., Perkin Trans. I 1973, 696.

5. Gluhareva, T.V.; Morzherin, Yu.Yu.; Mokrushin, V.S. Chem. Heterocycl. Comp. (Engl. Transl.) 2000, 36, 107.

6. Kirschke, K.; Möller, A.; Schmitz, E.; Kuban, R.J.; Schulz, B. Tetrahedon Lett. 1986, 27, 4281.

7. Martin, J.; Meth-Cohn, O.; Suschitzky, H. Tetrahedron Lett. 1973, 4495.

8. Tea Gokou, C.; Pradere, J.P.; Qiuniou, H. Synth. Commun. 1986, 16, 79.

9. Akiba, M.; Kosugi, Y.; Takada, T. J. Org. Chem. 1978, 43, 4472.

10. Suschitzky, H.; Walrond, R.E.; Hull, R. J. Chem.Soc., Perkin Trans. I 1977, 47.

11. Falci, K.J.; Franck, R.W.; Smith, G.P. J. Org. Chem. 1977, 42, 3317.

12. Fokin, E.P.; Russkikh, V.V. Zhur.Org. Khim. 1966, 2, 907.

13. Nijuis, W.H.N.; Verboom, W.; Harkema, S.; Reinhoudt, R. Recl. Trav. Chim. Pays-Bas 1989, $108,147$.

14. Verboom, W.; Reinhoudt, D.N. Rec. Trav. Chim. Pay-Bas 1990, 109, 311

15. Visser, G.W.; Verboom, W.; Benders, P.H.; Reinhoudt, D. J. Chem. Soc. Chem. Commun. 1982, 669.

16. Verboom, W.; Lammerink, B.H.M.; Egberink, R.J.M., Reinhoudt, D.N.; Harkema, S. J. Org. Chem. 1985, 50, 3797.

17. D'yachenko, E.V.; Glukhareva, T.V.; Mezenova, E.V., Zybina, N.A.; Lobodin, V.V.; Morzherin, Yu.Yu. Vestnik USTU-UPI. 2004. 7, 76-79.

18. Lobodin, V.V.; Ovcharenko, V.V.; Pihlaja, K.; Morzherin, Yu.Yu.; Lebedev, A.T. Rapid Comm. Mass Spectrom. 2004. 18, 724 - 728

19. Ojea, V.; Muinelo, I.; Figueroa, M.C.; Ruiz, M.; Quintela, J.M. Synlett. 1995, 622. 
20. Kaval, N.; Dehaen, W.; Matyus, P.; Van der Eycken, E. Green Chem. 2004, 125.

21. Melh-Cohn, O.; Suschiizky, H. Adv. Heterocycl. Chem., 1996, 65, 1

22. Verboom, W.; Reinhoudt, D.; Visser, R.; Harkema, S. J. Org.Chem. 1984, 49, 269.

23. Dijksman, W.C.; Verboom, W.;Egberink, R.; Reinhoudt, D. J. Org. Chem. 1985, 50, 3791.

24. Verboom, W.; Reinhoudt, D.N.; Visser, R.; Harkema, S.. J. Org. Chem. 1989, 54, 209

25. Verboom, W.; Morzherin, Yu.; Kelderman, E.; Engbersen, J.F.J.; van Hummel, G.J.; Harkema, S.; Reinhoudt, D.N. Recl. Trav. Chim. Pays-Bas 1993, 112, 549.

26. Glukhareva, T.V.; D'yachenko, E.V.; Morzherin, Yu.Yu. Prog. Org. Synth. (Ekaterinburg). 2003, 61.

27. Nijuis, W.; Verboom, W.; Reinhoudt, D.; Harkema, S. J. Am. Chem. Soc. 1987, 109, 3136.

28. Nijhuis, W.; Verboom, W.; Abu El-Fadl, A.; Harkema, S.; Reinhoudt, D. J. Org. Chem. 1989, 54, 209

29. Glukhareva, T.V.; D'yachenko, E.V.; Morzherin, Yu.Yu. Chem. Heterocycl. Comp. (Engl. Transl.), 2002, 38, 1426

30. D'yachenko, E.V.; Glukhareva, T.V.; Nikolaenko, E.F.; Tkachev, A.V.; Morzherin, Yu.Yu. Russ. Chem. Bull. (Intern. Ed.) 2004, 1194

31. D'yachenko, E.V.; Glukhareva, T.V.; Morzherin, Yu.Yu. Chem. Heterocycl. Comp. (Engl. Transl.), 2003, 39, 1532

32. Morzherin,Y.Y. Dissertation Tesis. Ekaterinburg (Russia). 2004.

Samples Availability: Available from the authors.

(C) 2005 by MDPI (http://www.mdpi.org). Reproduction is permitted for noncommercial purposes. 